\title{
Pengaruh Budaya Organisasi, Gaya Kepemimpinan, dan Pelatihan Terhadap Kinerja Karyawan Pada Kantor Dinas Tenaga Kerja Dan Transmigrasi Provinsi D.I Yogyakarta
}

\author{
Ika Aprilia Cahyani ${ }^{1}$, Jajuk Herawati ${ }^{2}$, Epsilandri Septyarini ${ }^{3}$ \\ Universitas Sarjanawiyata Tamansiswa \\ Correspondence email: ikaapriliacahyani10@gmail.com, jajuk.herawati@yahoo.com, epsilandriseptyarini@ustjogja.ac.id
}

\begin{abstract}
Abstrak. Kinerja karyawan mempengaruhi seseorang seberapa banyak memberikan peran serta kepada organisasi. Budaya organisasi yang baik dapat meningkatkan kinerja karyawan pada organisasi tersebut. Gaya kepemimpinan yang diterapkan oleh seorang pemimpin memiliki peran utama dalam tercapainya lingkungan kerja yang baik diorganisasi tersebut. Pelatihan merupakan proses pengembangan diri oleh karyawan agar bisa bekerja lebih terampil, meningkatkan pengetahuan dan keahlian pada seorang karyawan. Tujuan dari penelitian ini untuk mengetahui pengaruh budaya organisasi, gaya kepemimpinan dan pelatihan terhadap kinerja karyawan pada Kantor Dinas Tenaga Kerja dan Transmigrasi Provinsi D.I Yogyakarta. Responden pada penelitian ini berjumlah 75 orang karyawan di Kantor Dinas Tenaga Kerja dan Transmigrasi Provinsi D.I Yogyakarta. Metode penelitian yang digunakan kali ini menggunakan metode kuantitatif. Sedangkan metode analisis data yang digunakan antara lain uji validitas, uji reabilitas, uji regresi linier berganda, dan uji asumsi klasik. Hasil penelitian ini menunjukkan bahwa budaya organisasi berpengaruh signifikan terhadap kinerja karyawan, gaya kepemimpinan tidak berpengaruh signifikan terhadap kinerja karyawan, pelatihan berpengaruh signifikan terhadap kinerja karyawan, dan budaya organisasi, gaya kepemimpinan, dan pelatihan berpengaruh secara simultan terhadap kinerja karyawan.
\end{abstract}

Kata kunci : Budaya Organisasi, Gaya Kepemimpinan, Pelatihan, dan Kinerja Karyawan

\begin{abstract}
Employee performance affects how much a person contributes to the organization. A good organizational culture can improve employee performance in the organization. The leadership style adopted by a leader has a major role in achieving a good work environment in the organization. Training is a process of self-development by employees so that they can work more skillfully, increase the knowledge and expertise of an employee. The purpose of this study was to determine the effect of organizational culture, leadership style and training on employee performance at the Department of Manpower and Transmigration of the Province of D.I Yogyakarta. Respondents in this study amounted to 75 employees at the Department of Manpower and Transmigration of D.I Yogyakarta Province. The research method used this time using quantitative methods. While the data analysis methods used include validity test, reliability test, multiple linear regression test, and classical assumption test. The results of this study indicate that organizational culture has a significant effect on employee performance, leadership style has no significant effect on employee performance, training has a significant effect on employee performance, and organizational culture, leadership style, and training have a simultaneous effect on employee performance.
\end{abstract}

Keywords : Organizational Culture, Leadership Style, Training, and Employee Performance.

\section{Pendahuluan}

Menurut (Hasibuan, 2013 dalam Kawiana, 2018) kinerja karyawan merupakan suatu pekerjaan yang dapat dicapai seseorang dalam menjalankan tugas yang diberikan kepadanya berdasarkan keahlian, pengalaman, keseriusan dan waktu. Budaya organisasi akan berpengaruh semua aspek organisasi dan perilaku anggota organisasi yang kemudian menentukan kinerja anggota dan organisasi (Wirawan, 2007 dalam Putra, 2015). Gaya kepemimpinan adalah perilaku atau cara yang dipilih atau dipergunakan pemimpin dalam mempengaruhi pikiran, perasaan, sikap, dan perilaku para anggota organisasi bawahannya (Nawawi, 2013:115 dalam Tampi, 2014). Sukses atau gagal karyawan dalam prestasi kerja mungkin dipengaruhi oleh gaya kepemimpinan atasannya (Suranta, 2012:117 dalam Turang R, Kindangen Paulus, 2015). Pelatihan adalah setiap usaha untuk memperbaiki setiap performansi pekerja pada suatu pekerjaan tertentu yang sedang menjadi tanggungjawabnya, atau satu pekerjaan yang ada kaitannya dengan pekerjaannya (Gomes, 2003 dalam Uhing et al., 2015). Hasil penelitian Khaliq (2015), Aziz (2018), Suharto \& Nusantoro (2018), Rosyidah, Fadah, dan Tobing (2018), menjelaskan bahwa budaya organisasi termasuk nilai dan norma yang diterapkan terhadap karyawan dapat mempengaruhi tingkat kinerja karyawan secara efektif. Hasil tersebut didukung dengan pengujian statistik yang membuktikan bahwa berpengaruh positif dan signifikan indikator budaya organisasi terhadap kinerja karyawan. Reza (2010) dalam penelitiannya menjelaskan bahwa variabel gaya kepemimpinan berpengaruh positif terhadap kinerja karyawan. Hasil penelitian Mamangkey (2015) dimana dalam penelitian tersebut dan penelitian ini sama - sama menentukan bahwa pelatihan berpengaruh terhadap kinerja karyawan. 
Ika Aprilia Cahyani, Jajuk Herawati dan Epsilandri Septyarini, Pengaruh Budaya Organisasi, Gaya Kepemimpinan, dan Pelatihan Terhadap Kinerja Karyawan Pada Kantor Dinas Tenaga Kerja dan Transmigrasi Provinsi D.I Yogyakarta

Tujuan dari penelitian ini yaitu untuk mengetahui pengaruh budaya organisasi, gaya kepemimpinan, dan pelatihan terhadap kinerja karyawan pada kantor Dinas Tenaga Kerja dan Transmigrasi D.I.Yogyakarta.

\section{Metode}

Jenis penelitian ini menggunakan metode kuantitatif. Sumber data yang digunakan dalam penelitian ini berupa data primer yang diperoleh dari kuesioner yang disebarkan kepada responden. Dalam penelitian ini digunakan 5 jenjang skala, yaitu: 1 = Sangat Tidak Setuju (STS); 2 = Tidak Setuju (TS); 3 = Netral (N); 4 = Setuju (S); 5 = Sangat Setuju (SS).

Penelitian kali ini populasinya yaitu pegawai kantor Dinas Tenaga Kerja dan Transmigrasi Provinsi D.I.Yogyakarta. Jumlah populasi 75 orang. Teknik pengambilan sampel dalam penelitian ini adalah dengan sampling jenuh dengan memakai semua populasi sebagai sampel. Metode pengumpulan data menggunakan kuesioner yang diberikan langsung kepada karyawan di kantor Dinas Tenaga Kerja dan Transmigrasi Provinsi D.I.Yogyakarta. Penelitian ini dilakukan di kantor Dinas Tenaga Kerja dan Transmigrasi D.I Yogyakarta yang terletak di jalan Lingkar Utara Maguwoharjo, Depok, Sleman (55282) yang dilakukan pada 11 Februari 2021 - 22 Februari 2021.

\section{Hasil \\ Uji Validitas \\ Budaya Organisasi}

Tabel 1

Uji Validitas variabel Budaya organisasi

\begin{tabular}{|l|r|r|c|}
\hline Item & Rxy Hitung & Sig. & Keterangan \\
\hline BO1 & .318 & 0.1914 & Valid \\
\hline BO2 & .562 & 0.1914 & Valid \\
\hline BO3 & .228 & 0.1914 & Valid \\
\hline BO4 & .423 & 0.1914 & Valid \\
\hline BO5 & .391 & 0.1914 & Valid \\
\hline BO6 & .247 & 0.1914 & Valid \\
\hline BO7 & .357 & 0.1914 & Valid \\
\hline BO8 & .301 & 0.1914 & Valid \\
\hline
\end{tabular}

Sumber: data diolah

Tabel 1 diatas menunjukan bahwa 8 butir peryataan pada variabel karakteristik diatas menunjukan bahwa nilai $r_{\text {hitung }}>r_{\text {tabel }}$ yang artinya semua item variabel Budaya Organisasi adalah valid dan dapat digunakan untuk penelitian berikutnya.

Gaya Kepemimpinan

Tabel 2

Uji validitas variabel Gaya Kepemimpinan

\begin{tabular}{|l|r|r|c|}
\hline Item & Rxy Hitung & Sig. & Keterangan \\
\hline GK1 & .363 & 0.1914 & Valid \\
\hline GK2 & .655 & 0.1914 & Valid \\
\hline GK3 & .658 & 0.1914 & Valid \\
\hline GK4 & .418 & 0.1914 & Valid \\
\hline GK5 & .394 & 0.1914 & Valid \\
\hline GK6 & .373 & 0.1914 & Valid \\
\hline GK7 & .229 & 0.1914 & Valid \\
\hline GK8 & .402 & 0.1914 & Valid \\
\hline
\end{tabular}

Sumber: data diolah

Tabel 2 diatas menunjukan bahwa 8 butir peryataan pada variabel karakteristik diatas menunjukan bahwa nilai $r_{\text {hitung }}>r_{\text {tabel }}$ yang artinya semua item variabel Gaya Kepemimpinan adalah valid dan dapat digunakan untuk penelitian berikutnya. 
Ika Aprilia Cahyani, Jajuk Herawati dan Epsilandri Septyarini, Pengaruh Budaya Organisasi, Gaya Kepemimpinan, dan Pelatihan Terhadap Kinerja Karyawan Pada Kantor Dinas Tenaga Kerja dan Transmigrasi Provinsi D.I Yogyakarta

\section{Pelatihan}

Tabel 3

Uji Validitas Variabel Pelatihan

\begin{tabular}{|l|r|r|r|}
\hline \multicolumn{1}{|c|}{ Item } & Rxy Hitung & Sig. & Keterangan \\
\hline P1 & .375 & 0.1914 & Valid \\
\hline P2 & .410 & 0.1914 & Valid \\
\hline P3 & .288 & 0.1914 & Valid \\
\hline P4 & .365 & 0.1914 & Valid \\
\hline P5 & .304 & 0.1914 & Valid \\
\hline P6 & .367 & 0.1914 & Valid \\
\hline
\end{tabular}

Sumber: data diolah

Tabel 3 diatas menunjukan bahwa 6 butir peryataan pada variabel karakteristik diatas menunjukan bahwa nilai $r_{\text {hitung }}>r_{\text {tabel }}$ yang artinya semua item variabel Pelatihan adalah valid dan dapat digunakan untuk penelitian berikutnya.

\section{Kinerja Karyawan}

Tabel 4

Uji Validitas Variabel kinerja Karyawan

\begin{tabular}{|l|r|r|c|}
\hline Item & Rxy Hitung & Sig. & Keterangan \\
\hline KK1 & .388 & 0.1914 & Valid \\
\hline KK2 & .455 & 0.1914 & Valid \\
\hline KK3 & .266 & 0.1914 & Valid \\
\hline KK4 & .368 & 0.1914 & Valid \\
\hline KK5 & .293 & 0.1914 & Valid \\
\hline KK6 & .241 & 0.1914 & Valid \\
\hline KK7 & .329 & 0.1914 & Valid \\
\hline KK5 & .413 & 0.1914 & Valid \\
\hline
\end{tabular}

Sumber: data diolah

Tabel 4 diatas menunjukan bahwa 9 butir peryataan pada variabel kinerja Karyawan mempunyai nilai signifikansi lebih kecil dari 5\% dan nilai Rxy hitung lebih besar dari 0.1914 (Rxy tabel untuk $n=73$ dan $\alpha=5 \%$ ). semua item variabel valid dan dapat digunakan untuk penelitian berikutnya.

\section{Uji Reabilitas}

Tabel 5

Hasil Uji Reabilitas

\begin{tabular}{llll}
\hline Variabel & Cronbach's Alpha & Nilai Kritis & Keterangan \\
\hline BO & .662 & 0.6 & Reliabel \\
GK & .730 & 0.6 & Reliabel \\
P & .624 & 0.6 & Reliabel \\
KK & .630 & 0.6 & Reliabel \\
\hline
\end{tabular}

Sumber: data diolah

Tabel 5 diatas menunjukan bahawa semua variabel penelitian mempunyai alpha cronbach lebih besar dari 0,6. ke empat variabel penelitian yaitu Budaya organisasi, Gaya Kepemimpinan, Palatihan, Kinerja Karyawan dapat dikatakan reliable. 
Ika Aprilia Cahyani, Jajuk Herawati dan Epsilandri Septyarini, Pengaruh Budaya Organisasi, Gaya Kepemimpinan, dan Pelatihan Terhadap Kinerja Karyawan Pada Kantor Dinas Tenaga Kerja dan Transmigrasi Provinsi D.I Yogyakarta

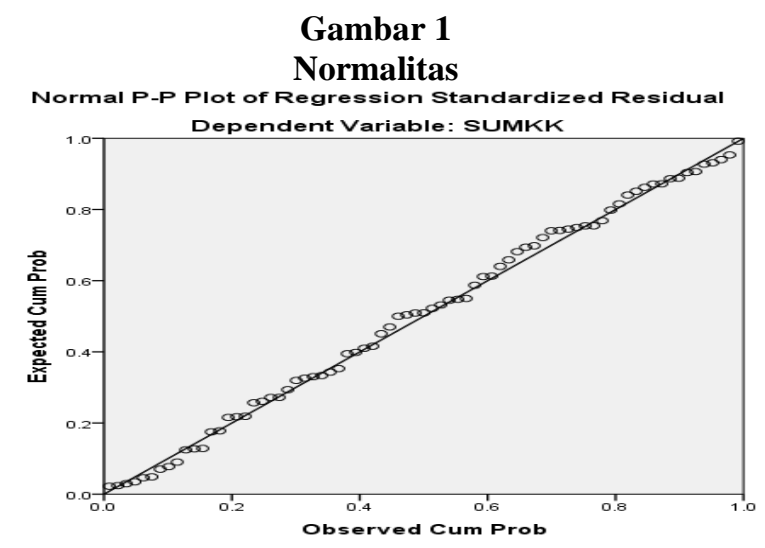

Sumber: data diolah

Berdasarkan gambar 1 diatas dapat diketahui bahwa penyebaran titik pada sumbu diagonal dari grafik normal P-P Plot variabel Atribut Produk dan WOM terhadap Keputusan Pembelian mengikuti adanya distribusi normal. Oleh karena itu, model regresi memenuhi asumsi normalitas.

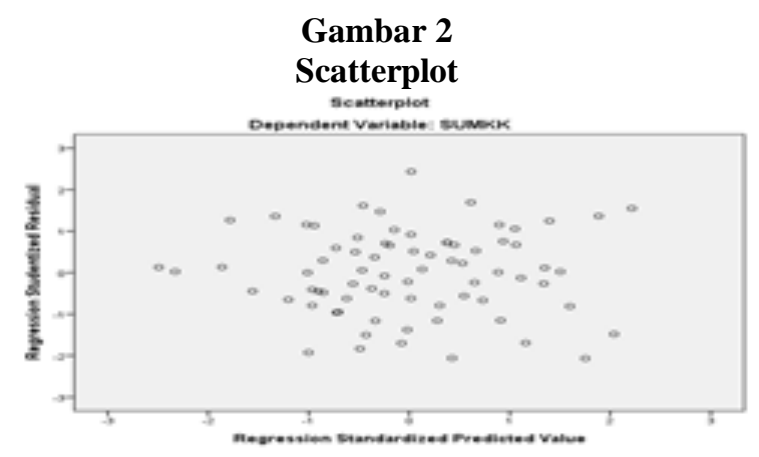

Sumber: data diolah

Berdasarkan gambar 2 diatas titik-titik pada scatterplot menyebar di kiri dan dikanan titik 0 pada sumbu $\mathrm{X}$ serta menyebar di bawah pada sumbu Y, dan juga tidak membentuk pola tertentu, ini menunjukan bahwa dalam regresi tersebut tidak terdapat gejala heteroskedastisitas.

Tabel 6

Hasil Uji Multikoloniaritas

\begin{tabular}{|ll|r|r|}
\hline \multirow{2}{*}{ Model } & \multicolumn{2}{|c|}{ Collinearity Statistics } \\
\cline { 2 - 4 } & (Constant) & Tolerance & VIF \\
& Sumbo & & .892 \\
\\
& Sumgk & .815 & 1.121 \\
& Sump & .779 & 1.228 \\
\hline
\end{tabular}

Sumber: data diolah

Berdasarkan Tabel 6 diatas menunjukan bahawa varaibel independen pada pengaruh Budaya organisasi, gaya Kepemimpinan dan Pelatihan terhadap Kinerja karyawan nilai tolerans $>0,10$ atau sama dengan nilai VIF <10, berarti tidak ada multikolinearitas antar variabel dalam model regresi.

Tabel 7

Hasil regresi BO, GK,P terhadap Kinerja karyawan

\begin{tabular}{|c|c|c|c|c|c|c|c|c|}
\hline \multirow{2}{*}{\multicolumn{2}{|c|}{ Mode1 }} & \multicolumn{2}{|c|}{ Unstandardized Coefficients } & \multirow{2}{*}{\begin{tabular}{|c} 
Standardized Coefficients \\
Beta
\end{tabular}} & \multirow[b]{2}{*}{$\mathrm{t}$} & \multirow[b]{2}{*}{ Sig. } & \multicolumn{2}{|c|}{ Collinearity Statistics } \\
\hline & & B & Std. Error & & & & Tolerance & VIF \\
\hline \multirow[t]{4}{*}{1} & (Constant) & 16.092 & 4.264 & & 3.774 & .000 & & \\
\hline & SUMBO & .334 & .107 & 33 & 3.132 & .003 & .892 & 1.121 \\
\hline & SUMGK & 037 & .081 & .05 & .453 & .652 & .815 & 1.228 \\
\hline & SUMP & 355 & .150 & .27 & 2.362 & .021 & .779 & 1.283 \\
\hline
\end{tabular}

Sumber: data diolah 
Ika Aprilia Cahyani, Jajuk Herawati dan Epsilandri Septyarini, Pengaruh Budaya Organisasi, Gaya Kepemimpinan, dan Pelatihan Terhadap Kinerja Karyawan Pada Kantor Dinas Tenaga Kerja dan Transmigrasi Provinsi D.I Yogyakarta

Berdasarkan hasil regresi pada tabel 4.17 maka dapat diperoleh persamaan regresi sebagai berikut:

$\mathrm{KK}=\mathrm{a}+\mathrm{b}_{1} \mathrm{BO}+\mathrm{b}_{2} \mathrm{GK}+\mathrm{b}_{3} \mathrm{P}+\mathrm{e}$

$\mathrm{KK}=16,092+0,334+0,037+0,355+\mathrm{e}$

\section{Uji Parsial (Uji t)}

a. Uji t digunakan untuk mengetahui pengaruh budaya Organisasi terhadap Kinerja Karyawan. Uji t yang dilakukan dengan cara membandingkan antara nilai $\mathrm{p}$ value dengan $\alpha(5 \%)$. Tingkat signifikansi untuk variabel Budaya Oraganisasi sebesar 0,003 ( $\mathrm{p}<0,05)$ dan t hitung sebesar 3.132(positif) maka dapat disimpulkan bahwa t hitung > $\mathrm{t}$ tabel( $3.132>1.993)$ dan signifikansi 0,003, maka hipotesis 1 diterima.

b. Uji t digunakan untuk mengetahui pengaruh Gaya Kepemimpinan secara sendiri-sendiri terhadap Kinerja karyawan. Uji t yang dilakukan dengan cara membandingkan antara nilai $\mathrm{p}$ value dengan $\alpha(5 \%)$. Tingkat signifikansi untuk variabel sebesar sebesar 0,652 (p>0,05) dan t hitung sebesar .653 (Negatif) maka dapat disimpulkan bahwa t hitung < $\mathrm{t}$ tabel $(.653<1.993)$ dan signifikansi 0,653>0,05, maka hipotesis 2 ditolak.

c. Uji t digunakan untuk mengetahui pengaruh Pelatihan terhadap Kinerja Karyawan. Uji t yang dilakukan dengan cara membandingkan antara nilai $\mathrm{p}$ value dengan $\alpha(5 \%)$. Tingkat signifikansi untuk variabel pelatihan sebesar $0,021(\mathrm{p}<0,05)$ dan $\mathrm{t}$ hitung sebesar 2.362(positif) maka dapat disimpulkan bahwa t hitung $>\mathrm{t}$ tabel $(2.362$ $>1.993$ ) dan signifikansi 0,021, maka hipotesis 3 diterima.

d. Budaya organisasi, gaya kepemimpinan, dan pelatihan secara simultan berpengaruh positif terhadap kinerja karyawan.

Tabel 8

Annova

\begin{tabular}{|c|c|c|c|c|c|c|}
\hline & & Sum of Squares & $\mathrm{df}$ & Mean Square & $\mathrm{F}$ & Sig. \\
\hline 1 & Regression & 181.665 & 3 & 60.555 & 8.590 & $.000^{\mathrm{b}}$ \\
\hline & Residual & 500.522 & 71 & 7.050 & & \\
\hline & Total & 682.187 & 74 & & & \\
\hline
\end{tabular}

Sumber: data diolah

Hasil analisis data dari Uji F, F hitung menunjukan nilai F sebesar $8.590>$ F table sebesar 2.50. atau dapat di lihat dengan nilai sig $0.000<0.05$ Maka dari table diatas menunjukan bahwa variable Budaya organisasi, Gaya Kepemimpinan, Pelatihan berpengaruh secara simultan terhadap kinerja karyawan.

\section{Koefisien Determinan}

Tabel 9

Model Summary

\begin{tabular}{|l|r|r|r|r|}
\hline \multicolumn{1}{|c|}{ Model } & \multicolumn{1}{c|}{ R } & \multicolumn{1}{c|}{ R Square } & Adjusted R Square & \multicolumn{1}{c|}{ Std. Error of the Estimate } \\
\hline 1 & $.516^{\mathrm{a}}$ & .266 & .235 & 2.655 \\
\hline
\end{tabular}

Sumber: data diolah

Hasil ini dapat diartikan bahawa variabel independen Budaya organisasi, gaya Kepemimpinan, Pelatihan mempengaruhi variabel dependen Kinerja Karyawan sebesar (23.5\%).

\section{Pengaruh Budaya Organisasi terhadap Kinerja karyawan}

Pengujian hipotesis pertama menunjukkan terdapat pengaruh yang signifikan Budaya organisasi terhadap Kinerja karyawan. responden menyatakan Saya melakukan persaingan yang sehat antar pegawai dalam melakukan pekerjaan (BO7) dengan rata-rata 4.52 lebih tinggi dari rata-rata yang lain dengan 40 responden menjawab Sangat Baik, 34 responden menjawab Baik, dan 1 responden menjawab netral, jawaban yang terendah pada (BO1) yang menyatakan Saya didorong untuk berfikir kreatif dalam mengerjakan pekerjaan saya dengan rata-rata 3.87 dengan 11 responden menjawab Sangat Baik, 38 responden menjawab baik, 7 responden menjawab cukup baik, dan 11 responden menjawab Tidak setuju. Hasil ini diperkuat oleh adanya penelitian yang mendukung budaya organisasi berpengaruh positif dan signifikan terhadap kinerja karyawan. Penelitian ini dilakukan oleh Brahmasari dan Siregar (2008), Shahzad et al (2013), dan Nurwati et al (2012) yang menghasilkan bahwa adanya pengaruh positif dan signifikan antara budaya organisasi terhadap kinerja karyawan. 
Ika Aprilia Cahyani, Jajuk Herawati dan Epsilandri Septyarini, Pengaruh Budaya Organisasi, Gaya Kepemimpinan, dan Pelatihan Terhadap Kinerja Karyawan Pada Kantor Dinas Tenaga Kerja dan Transmigrasi Provinsi D.I Yogyakarta

\section{Pengaruh Gaya Kepemimpinan terhadap Kinerja karyawan}

Pengujian hipotesis kedua menunjukkan terdapat pengaruh tidak signifikan gaya Kepemimpinan terhadap kinerja Karyawan responden menyatakan Pimpinan membiarkan kelompoknya berbuat semaunya sendiri (GK7) dengan rata-rata 4.32 lebih tinggi dari rata-rata yang lain dengan 29 responden menjawab sangat baik, 41 responden menjawab baik, dan 5 responden menjawab cukup baik, jawaban yang terendah pada (GK3) yang menyatakan Pimpinan menghargai potensi yang ada pada setiap bawahan dan mau mendengarkan nasehat bawahannya dengan rata-rata 3.55 dengan 19 responden menjawab sangat baik, 28 responden menjawab baik, 12 responden menjawab cukup baik, 7 responden menjawab tidak setuju, dan 9 responden menjawab sangat tidak baik. Hasil ini diperkuat oleh adanya penelitian yang mendukung yaitu hasil penelitian Dwi Haryanto (2017) yang meneliti pengaruh gaya kepemimpinan, kompensasi, dan komitmen organisasi terhadap kinerja karyawan menemukan bahwa gaya kepemimpinan tidak berpengaruh positif dan tidak signifikan terhadap kinerja karyawan.

\section{Pengaruh Pelatihan Terhadap Kinerja karyawan}

Pengujian hipotesis pertama menunjukkan terdapat pengaruh yang signifikan Pelatihan terhadap Kinerja karyawan. Responden Menyatakan menyatakan Materi pelatihan yang diberikan dapat meningkatkan keterampilan saya sesuai dengan kebutuhan pekerjaan (P4) dengan rata-rata 4.31 lebih tinggi dari rata-rata yang lain dengan 29 responden menjawab sangat baik, 40 responden menjawab baik, dan 40 responden menjawab cukup baik, jawaban yang terendah pada (P1) yang menyatakan Setelah mengikuti pelatihan anda mampu menyelesaikan pekerjaan dengan lebih mudah dan cepat dengan rata-rata 4.08 dengan 17 responden menjawab sangat baik, 47 responden menjawab baik, 11 responden menjawab cukup baik, Pelatihan akan memberikan kesempatan bagi karyawan mengembangkan keahlian dan kemampuan baru dalam bekerja agar apa yang diketahui dan di kuasai saat ini maupun untuk masa mendatang dapat membantu karyawan untuk mengerti apa yang sebenarnya dikerjakan. Hasil ini diperkuat oleh adanya penelitian yang mendukung pelatihan berpengaruh positif dan signifikan terhadap kinerja karyawan. Hasil penelitian Widhayu dkk (2013) yang meneliti pengaruh pendidikan dan pelatihan terhadap kinerja karyawan dan penelitian Leonardo (2013) yang meneliti pengaruh pelatihan dan motivasi kerja terhadap kinerja karyawan menemukan bahwa pelatihan berpengaruh positif dan signifikan terhadap kinerja karyawan.

\section{Pengaruh Budaya Organisasi, Gaya Kepemimpinan, dan Pelatihan terhadap Kinerja karyawan}

Hasil penelitian menunjukan bahwa Budaya Organisasi, gaya kepemimpinan dan Pelatihan berpengaruh secara simultan terhadap Kinerja karyawan Kantor Trasmigrasi DIY. Hasil analisis data dari Uji F, F hitung menunjukan nilai $\mathrm{F}$ sebesar $8.590>\mathrm{F}$ table sebesar 2.50. atau dapat di lihat dengan nilai sig $0.000<0.05$. Dengan demikian Budaya organisasi, gaya kepemimimpinan dan Pelatihan berpengaruh secara simultan terhadap kinerja karyawan.

\section{Simpulan}

1. Terdapat pengaruh budaya Organisasi terhadap Kinerja Karyawan. Uji t yang dilakukan dengan cara membandingkan antara nilai $\mathrm{p}$ value dengan $\alpha(5 \%)$. Tingkat signifikansi untuk variabel Budaya Oraganisasi sebesar 0,003 ( $\mathrm{p}<0,05)$ dan $\mathrm{t}$ hitung sebesar 3.132(positif) maka dapat disimpulkan bahwa t hitung $>\mathrm{t}$ tabel( $3.132>1.993$ ) dan signifikansi 0,003, maka hipotesis 1 diterima.

2. Terdapat pengaruh Gaya Kepemimpinan secara sendiri-sendiri terhadap Kinerja karyawan. Uji t yang dilakukan dengan cara membandingkan antara nilai $\mathrm{p}$ value dengan $\alpha(5 \%)$. Tingkat signifikansi untuk variabel sebesar sebesar 0,652 ( $p>0,05)$ dan t hitung sebesar .653 (Negatif) maka dapat disimpulkan bahwa $t$ hitung < $t$ tabel ( $.653<1.993$ ) dan signifikansi 0,653>0,05, maka hipotesis 2 ditolak.

3. Terdapat pengaruh Pelatihan terhadap Kinerja Karyawan. Uji t yang dilakukan dengan cara membandingkan antara nilai $\mathrm{p}$ value dengan $\alpha(5 \%)$. Tingkat signifikansi untuk variabel pelatihan sebesar $0,021(\mathrm{p}<0,05)$ dan $\mathrm{t}$ hitung sebesar 2.362(positif) maka dapat disimpulkan bahwa $t$ hitung $>\mathrm{t}$ tabel( $2.362>1.993)$ dan signifikansi 0,021 , maka hipotesis 3 diterima.

4. Hasil analisis data dari Uji F, F hitung menunjukan nilai F sebesar $8.590>\mathrm{F}$ table sebesar 2.50. atau dapat di lihat dengan nilai sig $0.000<0.05$ Maka dari table diatas menunjukan bahwa variable Budaya organisasi, Gaya Kepemimpinan, Pelatihan berpengaruh secara simultan terhadap kinerja karyawan.

\section{Daftar Pustaka}

Adinata, W. S. U. (2015). Pengaruh kepemimpinan transformasional, motivasi, dan budaya organisasi terhadap kinerja karyawan KJKS BMT Tamzis Bandung. Jurnal Ekonomi, Bisnis \& Entrepreneurship, 9(2), 136-157.

agus dwipayana, M., \& SUANA, W. (2014). Pengaruh Disiplin Kerja, Motivasi Dan Gaya Kepemimpinan Terhadap Kinerja Karyawan Pada Percetakan Sadha Jaya Di Denpasar. E-Jurnal Manajemen Universitas Udayana, 3(1), 253634. 
Ika Aprilia Cahyani, Jajuk Herawati dan Epsilandri Septyarini, Pengaruh Budaya Organisasi, Gaya Kepemimpinan, dan Pelatihan Terhadap Kinerja Karyawan Pada Kantor Dinas Tenaga Kerja dan Transmigrasi Provinsi D.I Yogyakarta

Amalia P, Widyaningrum M, dan S. (2018). Pengaruh Gaya Kepemimpinan, Budaya Organisasi, dan Pelatihan Terhadap Kinerja Karyawan Pada PT Hartono Elektronik Cabang Ahmad Yani. 4(3), 169-178.

Andayani, A. A., \& Soehari, T. D. (2019). Pengaruh Budaya Organisasi, Komitmen Organisasi dan Gaya Kepemimpinan terhadap Kinerja Karyawan. Akademika, 8(02), 129-145. https://doi.org/10.34005/akademika.v8i02.366

Anggereni, N. W. E. S. (2018). Pengaruh Pelatihan Terhadap Kinerja Karyawan Pada Lembaga Perkreditan Desa (Lpd) Kabupaten Buleleng. Jurnal Pendidikan Ekonomi Undiksha, $10(2), \quad 606$. https://doi.org/10.23887/jjpe.v10i2.20139

Ataunur, I., \& Ariyanto, E. (2015). Pengaruh Kompetensi dan Pelatihan terhadap Kinerja Karyawan PT. Adaro Energy Tbk. Telaah Bisnis, 16(2), 135-150.

Azwar, M. S. (2016). Pengaruh Gaya Kepemimpinan, Komunikasi, Dan Disiplin Kerja Terhadap Kinerja Karyawan. Jurnal Ilmu Dan Riset Manajemen, 5(3), 1-20.

Dedek, G. K. (2014). Pengaruh Budaya Organisasi Perusahaan Dan Motivasi Terhadap Kinerja Karyawan Pada Pt. Perusahaan Gas Negara (Persero) Tbk Medan. Applied Microbiology and Biotechnology, 14(02), 2071-2079. https://doi.org/10.1016/j.bbapap.2013.06.007

Desky, H. (2014). Pengaruh Etos Kerja Islami Dan Gaya Kepemimpinan Terhadap Kinerja Karyawan Rumah Makan Ayam Lepaas Lhokseumawe. Inferensi, 8(2), 459. https://doi.org/10.18326/infs13.v8i2.459-478

Dewi, S. P. (2012). Pengaruh Pengendalian Internal Dan Gaya Kepemimpinan Terhadap Kinerja Karyawan Spbu Yogyakarta (Studi Kasus Pada SPBU Anak Cabang Perusahaan RB. GRUP). Journal of Chemical Information and Modeling, 1(1), 1689-1699. file://C:/Users/User/Downloads/fvm939e.pdf

Dian, M. J. dan W. (2018). Pengaruh Budaya Organisasi Dan Gaya Kepemimpinan Terhadap Kinerja Karyawan Pada Pt. Neuronworks Indonesia Bandung. Isbn, 2(3), https://doi.org/10.1016/j.cell.2017.12.025\%0Ahttp://www.depkes.go.id/resources/download/info-terkini/hasilriskesdas-2018.pdf\%0Ahttp://www.who.int/about/licensing/

Dusauw, A. (2016). Pengaruh Pelatihan, Keterlibatan Kerja Dan Kompetensi Terhadap Kinerja Karyawan Pada PT. Bank Sulut Go Manado. Jurnal Riset Ekonomi, Manajemen, Bisnis Dan Akuntansi, 4(5), 551-510.

Effendy, A. A., \& Fitria, J. R. (2020). Pengaruh Gaya Kepemimpinan, Motivasi Dan Disiplin Kerja Terhadap Kinerja Karyawan (Studi Kasus PT. Modernland Realty, TBK). JENIUS (Jurnal Ilmiah Manajemen Sumber Daya Manusia), 3(3), 264. https://doi.org/10.32493/jjsdm.v3i3.4864

Indra Yudha, R. (2018). Pengaruh Budaya Organisasi dan Kepuasan Kerja Terhadap Kinerja Karyawan pada PT. Jaya Abadi Sumber Pasifik Kota Jambi. Manajemen Dan Kewirausahaan, 9(2), 24-35.

Kawiana, I. G. P. (2018). The influence of organizational culture, employee satisfaction, personality, and organizational commitment towards employee performance. International Research Journal of Management, IT and Social Sciences, 5(3), 35-45. https://doi.org/10.21744/irjmis.v5i3.666

Khairizah, A., Noor, I., \& Suprapto, A. (2015). Pengaruh gaya kepemimpinan terhadap kinerja karyawan (studi pada karyawan di Perpustakaan Universitas Brawijaya Malang). Jurnal Administrasi Publik (JAP), 3(7), 12681272.

Lolowang Grady Melvin, Adolfina, L. G. (2016). pengaruh pelatihan dan pengembangan sumber daya manusia terhadap kinerja karyawan pada PT. Berlian Kharisma Pasifik Manado. EMBA, 4(2), 177-186. https://doi.org/10.1080/00050326.1957.10437402

Marifa N, D. (2018). Pengaruh Pelatihan dan Motivasi Kerja Terhadap Kinerja Karyawan CV.Langgeng Makmur Bersama di Kabupaten Lumajang. Jurnal Riset Manajemen, 1(NO.2), 124-135.

Marta, J. D., \& Wijayati, D. T. (2016). Pengaruh Budaya Organisasi dan Komunikasi Organisasi terhadap Kinerja Karyawan PT. X. BISMA (Bisnis Dan Manajemen), 8(2), 218. https://doi.org/10.26740/bisma.v8n2.p218-236

Meutia, K. I., \& Husada, C. (2019). Pengaruh Budaya Organisasi dan Komitmen Organisasi Terhadap Kinerja Karyawan. 4(1), 119-126.

Muhammad, E. Z. G., \& Mukzam, M. D. (2017). Pengaruh Budaya Organisasi Terhadap Kinerja Karyawan (Studi pada Karyawan Bank BRI Kantor Cabang Tuban). 53(1), 89-95.

Muis, M. R., Jufrizen, J., \& Fahmi, M. (2018). Pengaruh Budaya Organisasi Dan Komitmen Organisasi Terhadap Kinerja Karyawan. Jesya (Jurnal Ekonomi \& Ekonomi Syariah), 1(1), 9-25. https://doi.org/10.36778/jesya.v1i1.7

Mukminin, A. A., Semmaila, B., \& Ramlawati, R. (2020). Effect of Education and Training , work discipline and Organizational culture on employee performance. 1(3), 19-28.

Mustikaningsih, yunita sari, \& Handayani, R. (2014). Pengaruh Gaya Kepemimpinan, Budaya Organisasi, Komitmen Organisasi Dan Remunerasi Terhadap Kinerja Karyawan. Media Ekonomi Dan Manajemen, 29(1), 44-58.

Novziransyah, N. (2017). Pengaruh Budaya organisasi terhadap Kinerja Karyawan PT. PLN (Persero) Kantor Wilayah Sumatera Utara Medan. Jurnal JUMANTIK, 2(1), 13-25. 
Ika Aprilia Cahyani, Jajuk Herawati dan Epsilandri Septyarini, Pengaruh Budaya Organisasi, Gaya Kepemimpinan, dan Pelatihan Terhadap Kinerja Karyawan Pada Kantor Dinas Tenaga Kerja dan Transmigrasi Provinsi D.I Yogyakarta

Pelatihan, P., Dan, K., Terhadap, M., Pada, K., Plasa, P. T., Krindo, M., Manajemen, J., \& Ekonomi, F. (2017). Pengaruh Pelatihan, Kompetensi Dan Motivasi Terhadap Kinerja Karyawan Pada Pt. Plasa Multi Krindo Manado. Jurnal EMBA: Jurnal Riset Ekonomi, Manajemen, Bisnis Dan Akuntansi, 5(3), 3048-3057. https://doi.org/10.35794/emba.v5i3.17350

Putra, S. W. (2015). Pengaruh Komitmen Organisasi, Budaya Organisasi, Gaya Kepemimpinan Dan Lingkungan Terhadap Kinerja Karyawan Pada Industri Kecil. Jurnal Ekonomi Modernisasi, 11(1), 62. https://doi.org/10.21067/jem.v11i1.869

Rachmawati, R. W. (2016). Pengaruh Pelatihan Dan Motivasi Kerja Terhadap Kinerja Karyawan Pt. Bank Bjb Kantor Cabang Suci Bandung. Jurnal Manajemen Dan Pemasaran Jasa, 9(1), 1. https://doi.org/10.25105/jmpj.v9i1.802

Razak, A., Sarpan, S., \& Ramlan, R. (2018). Effect of leadership style, motivation and work discipline on employee performance in PT. ABC Makassar. International Review of Management and Marketing, 8(6), 67-71.

Rosvita, V., \& Setyowati, E. (2017). Pengaruh Budaya Organisasi Terhadap Kinerja Karyawan. 2(1), 14-20.

Safitri, E. (2013). Pengaruh Pelatihan Dan Disiplin Kerja Terhadap kinerja Karyawan. Jurnal Ilmu Manajemen (JIM), l(4).

Setiawan, K., \& Mujiati, N. (2016). Pengaruh Gaya Kepemimpinan Dan Kompensasi Terhadap Kinerja Karyawan Pt. Astra Honda Nusa Dua Kabupaten Badung. None, 5(12), 242611.

Sulistyaningsih, D. S. A. dan W. T. (2012). Pengaruh Budaya Organisasi Terhadap Kinerja Karyawan UIN Sunan Kalijaga Yogyakarta. Profetik, 6(2).

Sunarsi, D. (2017). Pengaruh Gaya Kepemimpinan dan Disiplin Kerja Terhadap Kinerja Karyawan Pada CV. Usaha Mandiri Jakarta. JENIUS (Jurnal Ilmiah Manajemen Sumber Daya Manusia), 1(2), 1-24. https://doi.org/10.32493/jjsdm.v1i2.919

Tampi, B. J. (2014). Pengaruh Gaya Kepemimpinan dan Motivasi Terhadap Kinerja Karyawan Pada PT. Bank Negara Indonesia, TBK (Regional Sales Manado). Jurnal “Acta Diurna” Volume III. No.4., III(4), 1-20.

Tanuwibowo, M. H., \& Setiawan, R. (2015). Pengaruh Budaya Organisasi Dan Motivasi Kerja Terhadap Kinerja Karyawan Pada Pt Lestari Purnama Perkasa. Agora, 3(2), 60-69.

Tartika, R., Utami, H., \& Mukzam, M. (2017). Pengaruh Budaya Organisasi Terhadap Kinerja Karyawan (Studi Pada Karyawan PT. Toyota Auto2000 Sukun-Malang). Jurnal Administrasi Bisnis S1 Universitas Brawijaya, 45(1), 155-160.

Turang R, Kindangen Paulus, dan T. J. (2015). Influence of Leadership Style, Motivation, and Work Discipline on Employee Performance in Pt.Dayana Cipta. Jurnal Berkala Ilmiah Efisiensi, 15(4), 505-516.

Uhing, Y., Tumbel, A., \& Mamangkey, T. J. (2015). Pengaruh Pelatihan, Pengalaman Dan Lingkungan Kerja Terhadap Kinerja Karyawan Pada Pt. Bangun Wenang Beverages Company Manado. Jurnal Riset Ekonomi, Manajemen, Bisnis Dan Akuntansi, 3(1), 737-747.

Walsa, E. (2016). Pengaruh Gaya Kepemimpinan Dan Motivasi Terhadap Kinerja Karyawan PT Citra Pembina Pengangkutan Industries Batam. Jurnal Nasional, 13(1), 97-111.

Wardani, R., Mukzam, M., \& Mayowan, Y. (2016). Pengaruh Budaya Organisasi Terhadap Kinerja Karyawan (Studi Pada Karyawan PT Karya Indah Buana Surabaya). Jurnal Administrasi Bisnis S1 Universitas Brawijaya, 31(1), 58-65.

Wulandari, A., \& Alamanda, D. T. (2012). Pengaruh Pelatihan dan Disiplin Kerja Terhadap Kinerja Karyawan Pada Yayasan Pendidikan Telkom. Pengaruh Pelatihan Dan Disiplin Kerja Terhadap Kinerja Karyawan Pada Yayasan Pendidikan Telkom, 1(1), 1-12.

Yusuf, F., Shinta, M. R., \& Fransisco, S. (2020). The Influence of Training on Employee Performance in PT . Pelni ( Persero ) Jakarta. 2(3).

Zahriyah, U. W., Nayati Utami, H., \& Ruhana, I. (2015). Pengaruh Budaya Organisasi Terhadap Kinerja Karyawan (Studi Pada karyawan PT. PLN (Persero) Distribusi Jawa Timur Area Malang). Jurnal Administrasi Bisnis (JAB), 2(1), 1-7. 